ISSN 1678-3921

Journal homepage: www.embrapa.br/pab

For manuscript submission and journal contents, access: www.scielo.br/pab
Adroaldo Guimarães Rossetti ${ }^{(1 凶)}(3)$, Francisco das Chagas Vidal Neto ${ }^{(1)}$ and Levi de Moura Barros ${ }^{(1)}$

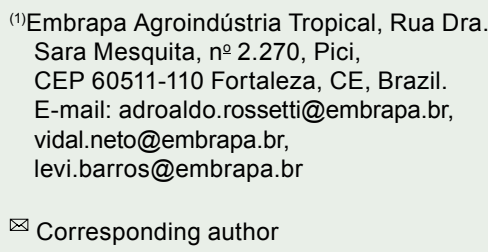

Accepted

November 20, 2018

How to cite

ROSSETTI, A.G.; VIDAL NETO, F. das C.; BARROS, L. de M. Sampling of cashew nuts as an aid to research for the genetic improvement of cashew tree. Pesquisa Agropecuária Brasileira, v.54, e00962, 2019. DOI: https://doi. org/10.1590/S1678-3921.pab2019.v54.00962.

\section{Sampling of cashew nuts as an aid to research for the genetic improvement of cashew tree}

\begin{abstract}
The objective of this work was to estimate sample sizes of cashew (Anacardium occidentale) nuts as an aid to the genetic improvement of cashew tree. Nuts were separated by size: nuts $<17 \mathrm{~mm}$ were classified as size 1 (S1); 17 $\mathrm{mm} \leq$ nuts $<19 \mathrm{~mm}$, size 2 (S2); $19 \mathrm{~mm} \leq$ nuts $<23 \mathrm{~mm}$, size 3 (S3); $23 \mathrm{~mm} \leq$ nuts $<25 \mathrm{~mm}$, size 4 (S4); and nuts $\geq 25 \mathrm{~mm}$, size 5 (S5). Sizing the sample for each stratum depends on the variance of nut size and on the error level B allowed for either the estimates or the desired precision in the results. The sample size will be larger the greater the variance of the stratum, the lower the error level allowed for the estimates, or the greater the precision desired in the results. For an error $\mathrm{B}=0.2 \mathrm{~g}$, the sample sizes of the $\mathrm{S} 5, \mathrm{~S} 4$, and $\mathrm{S} 3$ strata were $\mathrm{n}_{5}=42$ nuts, $\mathrm{n}_{4}=30$ nuts, and $\mathrm{n}_{3}=19$ nuts, respectively. In the S5 and S4 strata, with better nut classifications, the average weight was 12.71 and $9.76 \mathrm{~g}$, respectively. The Sm stratum - formed by the mixture of nuts of several sizes - should not be used as a parameter in this context due to its great variability, which is far larger than that of the other strata. Stratified sampling composed of six strata (S1, S2, ..., S5, Sm) is effective for estimating different sizes of nut samples.
\end{abstract}

Index terms: Anacardium occidentale, sample size, sampling precision, uniform stratified random sampling.

\section{Amostragem de castanha-de-caju como suporte às pesquisas de melhoramento genético do cajueiro}

Resumo - O objetivo deste trabalho foi estimar tamanhos de amostras de castanhade-caju (Anacardium occidentale) como suporte às atividades de melhoramento genético do cajueiro. As castanhas foram separadas por tamanho: castanhas $<17$ mm foram classificadas como tamanho 1 (S1); $17 \leq$ castanhas $<19 \mathrm{~mm}$, tamanho 2 (S2); $19 \leq$ castanhas $<23 \mathrm{~mm}$, tamanho 3 (S3); $23 \leq$ castanhas $<25 \mathrm{~mm}$, tamanho 4 (S4); e castanhas $\geq 25 \mathrm{~mm}$, tamanho 5 (S5). O dimensionamento da amostra de cada estrato depende da variância do tamanho da castanha e do nível de erro B admitido para as estimativas ou para a precisão desejada nos resultados. O tamanho da amostra será maior quanto maior for a variância do estrato, menor o nível de erro admitido nas estimativas, ou maior a precisão desejada nos resultados. Para um erro B $=0,2 \mathrm{~g}$, os tamanhos de amostra dos estratos S5, S4 e S3 foram $\mathrm{n}_{5}=42$ castanhas, $\mathrm{n}_{4}=30$ castanhas e $\mathrm{n}_{3}=19$ castanhas, respectivamente. Nos estratos S5 e S4, com melhor classificação de castanhas, as massas médias foram, respectivamente, 12,71 e 9,76 g. O estrato $\mathrm{Sm}$ - formado pela mistura de castanhas de diversos tamanhos - não deve ser utilizado como parâmetro nesse contexto, em razão de sua grande variabilidade, que é muito maior do que as dos demais estratos. A amostragem estratificada, composta por seis estratos (S1, S2, ..., S5, $\mathrm{Sm})$, é eficaz para estimar amostras de castanhas de diferentes tamanhos.

Termos para indexação: Anacardium occidentale, tamanho de amostra, precisão de amostragem, amostragem aleatória estratificada uniforme. 


\section{Introduction}

Cashew kernel is the principal and most important commercial product of cashew (Anacardium occidentale L.) tree, and is therefore essential to the selection process in projects for the genetic improvement of the crop. The fact that the kernel is enclosed in the nut makes it impossible to use it directly in the evaluation and selection of genotypes. It follows that the production, size, and weight of the nut are the most used characteristics for plant selection, both in commercial plantations and in research, particularly in the area of cashew tree genetic improvement (Paiva et al., 2005; Barros et al., 2008).

Although the existence of correlation between the variables size and weight of the nut shows a dependence relation between them, an evaluation based simply on this correlation may induce to errors in the selection process due to the large variability. Aliyu \& Awopetu (2011) found a coefficient of variation $(\mathrm{CV}=25 \%)$ in the kernel weight to nut weight ratio, and in the weight of kernel $(\mathrm{CV}=40.68 \%)$ and nut $(\mathrm{CV}=52.02 \%)$ respectively. To evaluate the weight and size characteristics of all fruit of all plants in these experiments, and even of all plants in one plot, is impossible in practice, as cashew trees produce a large amount of fruit during the season. Therefore, it is essential to employ sampling techniques with a suitable sizing, which can act as reliable estimators of these characteristics.

Studies involving sampling are however always subject to some degree of uncertainty, as only part of the population is evaluated. Such uncertainty can be reduced by collecting a greater number of sampling units (or larger samples), and using better measuring instruments. Consequently, specifying the level of precision desired in the results is an extremely important precaution, as it indicates the size of the error permitted, or tolerated, and the probability of this error occurring during the sampling plan, or in the precision of the sampling process (Cochran, 1977).

Several studies, for various purposes, have been carried out based on samples of reproductive agronomic characteristics and of nut and kernel of cashew. However, none of these mentioned the level of precision desired in the results, which weakens the drawn conclusions. Aliyu (2006) used a sample of 40 cashew nuts to analyse the production components of the cashew tree, and to quantify the phenotypic relationships between nut production and other agronomic characteristics, and found significant positive correlations, from $r=0.844$ to $r=0.988$, between production and agronomic characteristics.

Aliyu \& Awopetu (2011) collected 50 fruit to evaluate the relationships between size and weight of nut, the size and weight of the kernel, and kernel to nut ratio, associating them to market requirements. Chacko (1997) used a sample of 100 nuts per plant to determine the nut mean weight and to identify trees with highyield potential, capable of producing medium to large nuts $(6 \mathrm{~g}$ to $10 \mathrm{~g})$, and kernels over $1.8 \mathrm{~g}$.

Almeida et al. (1992) studied the physical characteristics of nuts and kernels from the progeny of fourdwarf cashew clones, CCP 06, CCP 09, CCP 76, and CCP 1001, to evaluate the respective genotypes based on these characteristics. Among other characteristics, they evaluated the weight, length, width, and thickness of the nut, in a sample of 40 nuts harvested at random from each parent plant. Garruti \& Cordeiro (1993) took samples of 25 nuts per clone to evaluate, among other biometric characteristics, the weight, length and diameter of nuts in four clones. Sardinha et al. (1998), with the aim of selecting superior genotypes and expanding the cashew germplasm collection in Guinea-Bissau, selected 42 trees, taking a sample of 20 nuts from each tree, to evaluate the following physical characteristics: length, width, greatest thickness, and smallest thickness.

Vale et al. (2014) estimated genetic parameters and potential production performance in seven fullsib progeny originating from dwarf cashew crosses. Among other characteristics, these authors evaluated the production $\left(\mathrm{kg} \mathrm{ha}^{-1}\right)$ and mean nut weight $(\mathrm{g})$, estimated from a sample of 20 nuts per progeny; and nuts in a same sample were weighed together. Cavalcanti et al. (2012) evaluated the production potential of 84 cashew clones, estimated genetic parameters and identified quantitative trait loci (QTL) associated with disease and various plant characteristics, such as production $\left(\mathrm{kg} \mathrm{ha}^{-1}\right)$ and nut weight $(\mathrm{g})$. A sample of 20 nuts from each clone was harvested to estimate nut weight, which varied from $4.15 \mathrm{~g}$ to $12.48 \mathrm{~g}$, with a mean of $7.41 \mathrm{~g}$.

Lima et al. (2015) developed a "simplified protocol" to operationalize the processing of cashew nuts, as an aid to the evaluation and selection of progeny from the cashew genetic improvement project. For it, they established the sample size of 100 nuts. There was no 
mention of the level of precision in the result regarding this sample size, or of the sampling methodology used, which may weaken its application in further research.

The objective of this work was to estimate sample sizes for cashew nuts, specifying the size of the error permitted or tolerated in the estimates, and the desired levels of precision in the results, as an aid to programmes of genetic improvement.

\section{Materials and Methods}

The base population of this research was represented by a mixture of nuts of different sizes, from the 2015/2016 harvest, originating from experiments with open-pollinated hybrid progenies including the dwarf cashew and common cashew.

The experiments were carried out in the experimental area of Embrapa Agroindústria Tropical, in the municipality of Pacajus ( $4^{\circ} 11^{\prime} 27^{\prime \prime} \mathrm{S}, 38^{\circ} 29^{\prime} 51^{\prime \prime} \mathrm{W}$, at $60 \mathrm{~m}$ altitude), in the state of Ceará, Brazil, so as to include the greatest possible variation in the characteristics under study. Nuts were harvested on the ground, under the crowns of the various genotypes, without identifying the genotype from which they came.

After harvesting, nuts were spread out in the sun to dry for three days in a cement-based dryer, and turned over several times daily, as recommended by Paiva \& Silva Neto (2013). Under such conditions, this drying time is sufficient to reduce moisture to $10 \%$ for storage, according to Lima (2013).

After the drying period, nuts were separated by size in a cylindrical sorter of perforated plates, with circular meshes from $17 \mathrm{~mm}$ to $25 \mathrm{~mm}$ diameter (Figure 1) which allow of nuts to pass through according to size. The $17 \mathrm{~mm}$ meshes allowed of the smallest nuts to pass through, which for the purpose of this work were classified as size 1 (S1); the $19 \mathrm{~mm}$ meshes allowed of nuts size $2(\mathrm{~S} 2>\mathrm{S} 1) ; 23 \mathrm{~mm}$ meshes allowed of nuts size $3(\mathrm{~S} 3>\mathrm{S} 2)$; and $25 \mathrm{~mm}$ meshes, allowed nuts size 4 $(\mathrm{S} 4>\mathrm{S} 3)$ to pass through. Size $5(\mathrm{~S} 5>\mathrm{S} 4)$, represented by large nuts that pass over each mesh without passing through any of them, were send directly to the receiver at the far right of the sorter (Figure $1 \mathrm{C}$ ).

After sorting, nuts were packed into plastic boxes, with the identified sizes (S1 to S5) selected by the sorter. In addition, one more set representing the original batch of nuts was obtained by random selection from several points in the dryer. In this set, nuts were collected from each point, without being separated by size, that is, a mix of different sizes identified as $\mathrm{Sm}$, and packed into a plastic box as the other sizes.

As a result, the study followed a design of uniform stratified random sampling, which consists of subdividing the population into homogeneous subgroups (strata), in such a way as to have homogeneity within strata, and heterogeneity between them (Cochran, 1977; Scheaffer et al. 2011; Ryan, 2013). The sampling plan consisted of six strata; each stratum was represented by a nut size (S1, S2, ..., S5, Sm). Three samples of 200 nuts were then randomly removed from each stratum and they were not replaced; these samples were then identified and separately packed into plastic bags. The remaining nuts were returned to their respective boxes.

Each sample was cleaned by removing any nuts considered unsuitable for industry (shrivelled, punctured or damaged), and also foreign matter such as sand, stones etc. The shrivelled, punctured and damaged nuts found in each sample were replaced by intact nuts of the same size, removed from their respective boxes. Nuts from each sample were individually weighed on
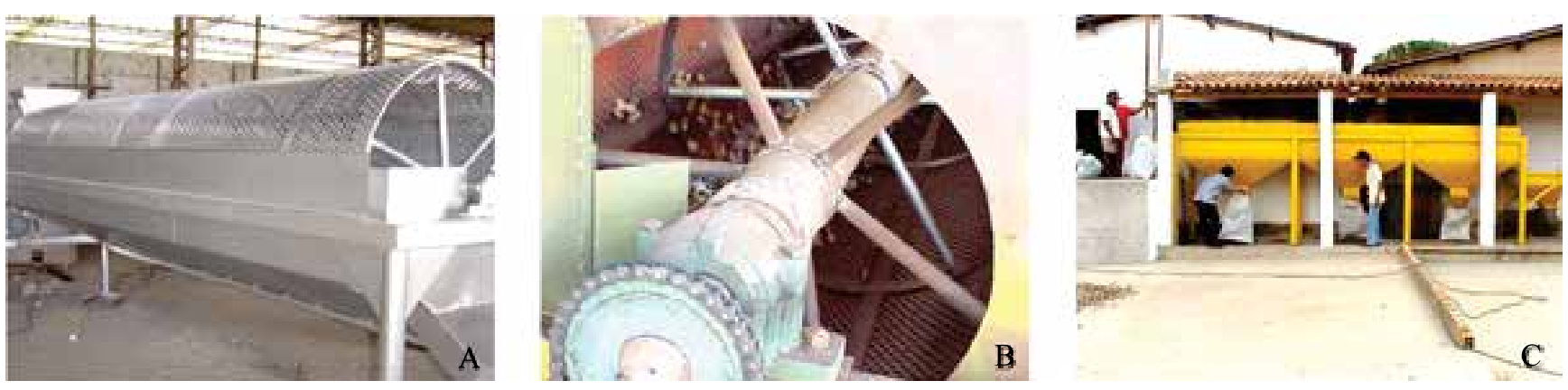

Figure 1. Sorting cashew (Anacardium occidentale) nuts by size: A, general view of the sorter; B, sorter with nuts during the sorting process; $\mathrm{C}$, nuts being placed in the sorter and removed by size. Photo by Cláudio de Norões Rocha. 
a BEL model S2202 electronic balance with 2,000 g maximum capacity and $0.01 \mathrm{~g}$ precision.

Composed as above, the strata fit the principles established by Scheaffer et al. (2011) and Pfeffermann \& Rao (2009), that is, large strata of a similar size. After weighing the nuts, the normality hypothesis was proved for the weight variable in each stratum. Under such conditions, where the $\alpha$ level $=0.05$ probability, the standard normal quantile is approximately 2.0. Therefore, the mean variance in a sampling plan precision is associated with the maximum level for error B permitted in the estimates, or levels of precision desired in the results, that is, $\sigma^{2}=B^{2} / 4$. According to Scheaffer et al. (2011) and Pfeffermann \& Rao (2009), under these conditions, and assuming that the cost of observation is the same for all strata, the allocation or sample size $n_{i}$, of the $i^{\text {th }}$ stratum (Neyman allocation) is obtained by

$$
\mathrm{n}_{\mathrm{i}}=\mathrm{n}\left(\frac{\mathrm{N}_{\mathrm{i}} \sigma_{\mathrm{i}}}{\sum_{\mathrm{k}=1}^{\mathrm{L}} \mathrm{N}_{\mathrm{k}} \sigma_{\mathrm{k}}}\right),
$$

in which: $L$ is the number of strata, in this case 6 (the six sizes of nut); $\mathrm{N}_{\mathrm{i}}$ is the size of the $\mathrm{i}^{\text {th }}$ stratum ( $\mathrm{i}=1$, $2, \ldots, 6) ; \sigma_{i}$ is the standard deviation of the $i^{\text {th }}$ stratum $(\mathrm{i}=1,2, \ldots, 6) ; \mathrm{N}_{\mathrm{k}}$ is the sample size of the $\mathrm{k}^{\text {th }}$ stratum $(\mathrm{k}=1,2, \ldots, 6) ; \sigma_{\mathrm{k}}$ is the standard deviation of the sample of the $\mathrm{k}^{\text {th }}$ stratum $(\mathrm{k}=1,2, \ldots, 6)$; and, $\mathrm{n}$ is the total sample size.

Under these conditions $\mathrm{i}=\mathrm{k}$, therefore:

$$
\mathrm{n}_{\mathrm{i}}=\mathrm{n}\left(\frac{\sigma_{\mathrm{i}}}{\sum_{\mathrm{i}=1}^{\mathrm{L}} \sigma_{\mathrm{i}}}\right) \text {, }
$$

\section{Equation 1,}

and the total size of sample $\mathrm{n}$, according to Scheaffer et al. (2011), is given by

$$
\mathrm{n}=\frac{\left(\sum_{\mathrm{k}=1}^{\mathrm{L}} \mathrm{N}_{\mathrm{k}} \sigma_{\mathrm{k}}\right)^{2}}{\mathrm{~N}^{2} \mathrm{D}+\sum_{\mathrm{i}=1}^{\mathrm{L}} \mathrm{N}_{\mathrm{i}} \sigma_{\mathrm{i}}^{2}} \text {. }
$$

As $\mathrm{i}=\mathrm{k}$, then

$$
\mathrm{n} \approx \frac{\left(\sum_{\mathrm{i}=1}^{\mathrm{L}} \mathrm{N}_{\mathrm{i}} \sigma_{\mathrm{i}}\right)^{2}}{\mathrm{~N}^{2} \mathrm{D}+\sum_{\mathrm{i}=1}^{\mathrm{L}} \mathrm{N}_{\mathrm{i}} \sigma_{\mathrm{i}}^{2}}, \quad \text { Equation 2, }
$$

in which: $\mathrm{N}$ is the number of sampling units in the population: $\mathrm{N}=\mathrm{N}_{1}+\mathrm{N}_{2}+\ldots+\mathrm{N}_{\mathrm{L}}$; is the variance of the $\mathrm{i}^{\text {th }}$ stratum $(\mathrm{i}=1,2, \ldots, 6)$; $\mathrm{D}$ is the estimator of the fixed mean variance in the sampling plan precision, associated with the maximum error permitted in the estimates $-\mathrm{D}=\mathrm{B}^{2} / 4$.

With the variances $\left(\mathrm{s}^{2}\right)$ and respective standard deviations (s) estimated for each stratum, substituted into equations 1 and 2 , the sample sizes $n_{i}(i=1,2, \ldots$, 6) were estimated for each stratum, and the total size of sample $\mathrm{n}$, for the maximum error level $\mathrm{B}$ permitted in the estimates, or the precision desired in the results. As there must be a relationship between the values set for $\mathrm{B}$ and the unit of measure of the phenomenon under study, and the values for nut weight are relatively low, they should be carefully chosen. In view of this, the magnitude permitted for B where: $0.1 \mathrm{~g}, 0.2 \mathrm{~g}, 0.3 \mathrm{~g}$, $0.4 \mathrm{~g}, 0.5 \mathrm{~g}, 0.6 \mathrm{~g}, 0.7 \mathrm{~g}, 0.8 \mathrm{~g}, 0.9 \mathrm{~g}$, and $1.0 \mathrm{~g}$; from these values, and taking the variances and standard deviations, the total sample size and the sample size of each stratum were estimated.

\section{Results and Discussion}

Assuming $\mathrm{B}=0.2 \mathrm{~g}$ as the maximum error level in the estimates, or level of precision desired in the results, the sample size of nut stratum S4, whose variance is $\mathrm{s}^{2}=1.9315$, is $\mathrm{n}_{4}=30$ nuts. For stratum $\mathrm{S} 5$, whose variance is $\mathrm{s}^{2}=3.7166$, the sample size is $\mathrm{n}_{5}=$ 42 nuts. Note that for the same level of error permitted in the estimates, or precision desired in the results, the sample size varies as a function of the variance of the stratum. The smaller nut strata S2 and S1, as they are the most uniform, showed smaller variances, $s^{2}=0.3641$ and $s^{2}=0.3285$, respectively (Table 1 ), and make it possible to obtain samples of smaller sizes, whatever the error level of the estimates, or precision desired in the results (Table 2).

The largest variance $\left(\mathrm{s}^{2}=5.3366\right)$ was recorded and, therefore, the largest sample size was obtained, in the $\mathrm{Sm}$ nut stratum. For a value B of $0.2 \mathrm{~g}$, the sample size is $\mathrm{n}_{\mathrm{m}}=50$ nuts. Under these conditions, the total sample size would be $\mathrm{n}=165$ nuts. Assuming $\mathrm{B}=0.1 \mathrm{~g}$, the sample size is $\mathrm{n}_{\mathrm{m}}=198$ nuts, and the total size, $\mathrm{n}=$ 657 nuts, as expected, they are the largest sample sizes, whatever the level of B. It should be noted that the lower the error level permitted in the estimates, or the greater the precision desired in the results (B), the larger will be the sample size, whatever the size of the nut. 
The stratum Sm, formed by the mixture of nuts of several sizes, should not be used as a parameter in this context due to its great variability, which is far larger than the other strata. The total size of sample $n$ of stratum $\mathrm{Sm}$ is $70.45 \%$ greater than the total sample size $n$ of the strata $\mathrm{S} 5, \mathrm{~S} 4, \ldots, \mathrm{S} 1$, irrespective of the error level B permitted in the estimates, or accuracy desired in the results. As it did not represent the reality of the research or of marketing, it was not included in Table 2, which only shows samples of the nut size strata S5, S4, ..., S1.

These results agree with those of Thompson (2012), Pfeffermann \& Rao (2009), and Ryan (2013), among others, according to whom three factors influence the sample size, as follows: confidence level (the higher the confidence level, the larger the sample size); maximum error permitted in the estimates (the smaller the permitted error, the larger the sample size); and variability of the phenomenon being investigated (the greater the variability, the larger the sample size). Data shown serve as a basis for choosing the sample size to be used in research that requires sampling of the cashew nut, based on the level of error of the estimate that the researcher will accept as reasonable, and on the precision desired in the results of the research (Table 2).

The use of stratified random sampling in this case was configured as in the literature as regards reducing sampling error and improving estimate precision, as reported by Ryan (2013) and Scheaffer et al. (2011), and Sabino \& Villaça (1999). Rossetti (2001), in a preliminary study to estimate the mean weight of cashew nut using only a simple random sample, obtained $\mathrm{B}=0.1 \mathrm{~g}$ and the same nut size strata values of $\mathrm{n}_{5}=1,487 ; \mathrm{n}_{4}=773$ and $\mathrm{n}_{3}=312$ nuts. Comparing those results with those obtained in the present study (Table 2), it is possible to confirm the effectiveness of the stratified random sampling.

Despite heavier kernels have a higher-market value, the indirect indicators used in the selection of genotypes that produce them are the size and weight of the nut, while no analysis of the kernel is available. Considering the most marketed class in the world (W 320), with $1.5 \mathrm{~g}$ kernel weight (Garruti et al., 2015) and desirable kernel to nut yield of $25 \%$, the nut weight is equal to $6.0 \mathrm{~g}$. However, taking into account the preference of Brazilian producers for larger kernels, a nut with $8.0 \mathrm{~g}$ is the adopted reference value for the genetic improvement at Embrapa Agroindústria Tropical, which employs the following classification: small nut (weight $<8 \mathrm{~g}$ ), medium nut $(8 \mathrm{~g} \leq$ weight $<12$ g) and large nut (weight $\geq 12 \mathrm{~g}$ ). Based on this premise, these parameters - which give an idea of the position of each stratum in the context of this classification (Table 3) - were estimated for each nut size (stratum) in the present research. It can be seen that the variance decreases according to nut size (Table 1), indicating a greater uniformity in the smaller nuts.

Examining the position of each stratum for the classification of the area for genetic improvement of cashew tree, it can be seen that the S5 and S4 nut strata are the most represented in this context (Table 3). In the first case (S5), 62.83\% of the nuts are large (weight $\geq 12 \mathrm{~g}$ ), with no small nuts (weight $<8 \mathrm{~g}$ ). Those of medium size ( $8 \mathrm{~g} \leq$ weight $<12 \mathrm{~g})$ are $37.17 \%$, with $12.71 \mathrm{~g}$ mean nut weight (Table 1). In the second case (S4), although there are only $6.17 \%$ large nuts (weight $\geq 12 \mathrm{~g}), 86 \%$ are medium-sized nuts $(8 \mathrm{~g} \leq$ weight

Table 1. Observed weights of minimum, maximum, and mean, and measurements of cashew (Anacardium occidentale) nut variability in the strata.

\begin{tabular}{lcccccc}
\hline Statistical analyses & \multicolumn{3}{c}{ Strata } \\
\cline { 2 - 6 } & S5 & S4 & S3 & S2 & S1 & Sm \\
\hline Minimum (g) & 8.40 & 6.00 & 6.00 & 4.00 & 1.80 & 1.00 \\
Maximum (g) & 21.80 & 14.60 & 10.00 & 7.20 & 5.20 & 15.80 \\
Mean (g) & 12.71 & 9.76 & 7.26 & 5.29 & 3.84 & 6.79 \\
Variance (s ${ }^{2}$ Standard deviation (s) & 3.7166 & 1.9315 & 0.7797 & 0.3641 & 0.3285 & 5.3366 \\
Coefficient of variation (\%) & 1.9278 & 1.3898 & 0.8830 & 0.6034 & 0.5731 & 2.3101 \\
\hline
\end{tabular}


$<12 \mathrm{~g}$ ), with $9.76 \mathrm{~g}$ mean nut weight (Table 1), which is higher than the $8.4 \mathrm{~g}$ of CCP 76 found by Ribeiro et al. (2004), and in agreement with the producers preference. Therefore, taking as an example $\mathrm{B}=0.2 \mathrm{~g}$ applied to the mean of the S4 stratum $(9.76 \mathrm{~g})$, which contains the minimum nut size for selection $(8 \mathrm{~g})$, it can be seen that this represents only $2.05 \%$, which may be considered sufficient for the process.

In the S3 stratum, there were no large nuts, and the greatest proportion $-78.67 \%$ - were small nuts (weight $<8 \mathrm{~g}$ ). Although $21.33 \%$ of the nuts were of medium size ( $8 \mathrm{~g} \leq$ weight $<12 \mathrm{~g}$ ), the mean nut weight was $7.26 \mathrm{~g}$ (Table 1), slightly below the preferred one by Brazilian producers. Whereas, the S2 and S1 nut strata, in which $100 \%$ of the nuts were small (weight $<8 \mathrm{~g}$ ), the mean weight ranged from $5.29 \mathrm{~g}$ to $3.84 \mathrm{~g}$ (Table 1).

The weight variability within the size classes (Table 1) is a result of the criteria adopted for the practical convenience of carrying out the activities of a genetic improvement project, with a view to meeting the demands of domestic producers. These criteria differ slightly from those established in the marketing standards for cashew nut (Brasil, 1975), in which the classes are: large nut (weight $\geq 11.11 \mathrm{~g}$ ), medium nut (7.14 $\mathrm{g} \leq$ weight $<11.11 \mathrm{~g})$, small nut $(4.55 \mathrm{~g} \leq$ weight $<7.14 \mathrm{~g}$ ), and tiny nut (weight $<4.55 \mathrm{~g}$ ). Even so, a coincidence of at least $62.83 \%$ (S5) was observed.

Some variability can still be introduced by the position at which the nut passes through the sorter mesh, as well as by its morphometry, in relation to length and width (Figure 2). In the first case, nuts of sizes S3 or S2 for instance, may occasionally fall into the S5 or S4 sized meshes, the same occurring in the other cases. In the second case, nuts of different widths can pass through different meshes, and have their weights grouped in the same class due to length (Figure 2). These situations may contribute to the increase of variance and, consequently, of sample size.

Table 2. Total sample sizes for cashew (Anacardium occidentale) nut (n) by size class (n5, n4, ..., n1), as a function of the maximum error (B) allowed for the estimates, or desired precision in the results.

\begin{tabular}{|c|c|c|c|c|c|c|}
\hline B & $\mathrm{n}$ & $\mathrm{n}_{5}$ & $\mathrm{n}_{4}$ & $\mathrm{n}_{3}$ & $\mathrm{n}_{2}$ & $\mathrm{n}_{1}$ \\
\hline 0.1 & 463 & 166 & 120 & 76 & 52 & 49 \\
\hline 0.2 & 116 & 42 & 30 & 19 & 13 & 12 \\
\hline 0.3 & 52 & 19 & 13 & 9 & 6 & 5 \\
\hline 0.4 & 29 & 10 & 8 & 5 & 3 & 3 \\
\hline 0.5 & 19 & 7 & 5 & 3 & 2 & 2 \\
\hline 0.6 & 13 & 5 & 3 & 2 & 2 & 1 \\
\hline 0.7 & 10 & 3 & 3 & 2 & 1 & 1 \\
\hline 0.8 & 8 & 3 & 2 & 1 & 1 & 1 \\
\hline 0.9 & 6 & 2 & 1 & 1 & 1 & 1 \\
\hline 1.0 & 5 & 1 & 1 & 1 & 1 & 1 \\
\hline
\end{tabular}

Table 3. Percentage of cashew (Anacardium occidentale) nuts according to their classification in the six strata by the criteria adopted for genetic improvement of cashew tree.

\begin{tabular}{lcccccc}
\hline Nut weight classification & \multicolumn{5}{c}{ Strata (nut size) } \\
\cline { 2 - 6 } & Nut S5 & Nut S4 & Nut S3 & Nut S2 & Nut S1 & Nut Sm \\
\hline Big - weight $\geq 12 \mathrm{~g}(\%)$ & 62.83 & 6.17 & 0.00 & 0.00 & 0.00 & 2.83 \\
Medium $-8 \mathrm{~g} \leq$ weight $<12 \mathrm{~g} \mathrm{( \% )}$ & 37.17 & 86.00 & 21.33 & 0.00 & 0.00 & 25.50 \\
Small - weight $<8 \mathrm{~g}(\%)$ & 0.00 & 7.83 & 78.67 & 100.00 & 100.00 & 71.67 \\
\hline Total $(\%)$ & 100.00 & 100.00 & 100.00 & 100.00 & 100.00 \\
\hline
\end{tabular}



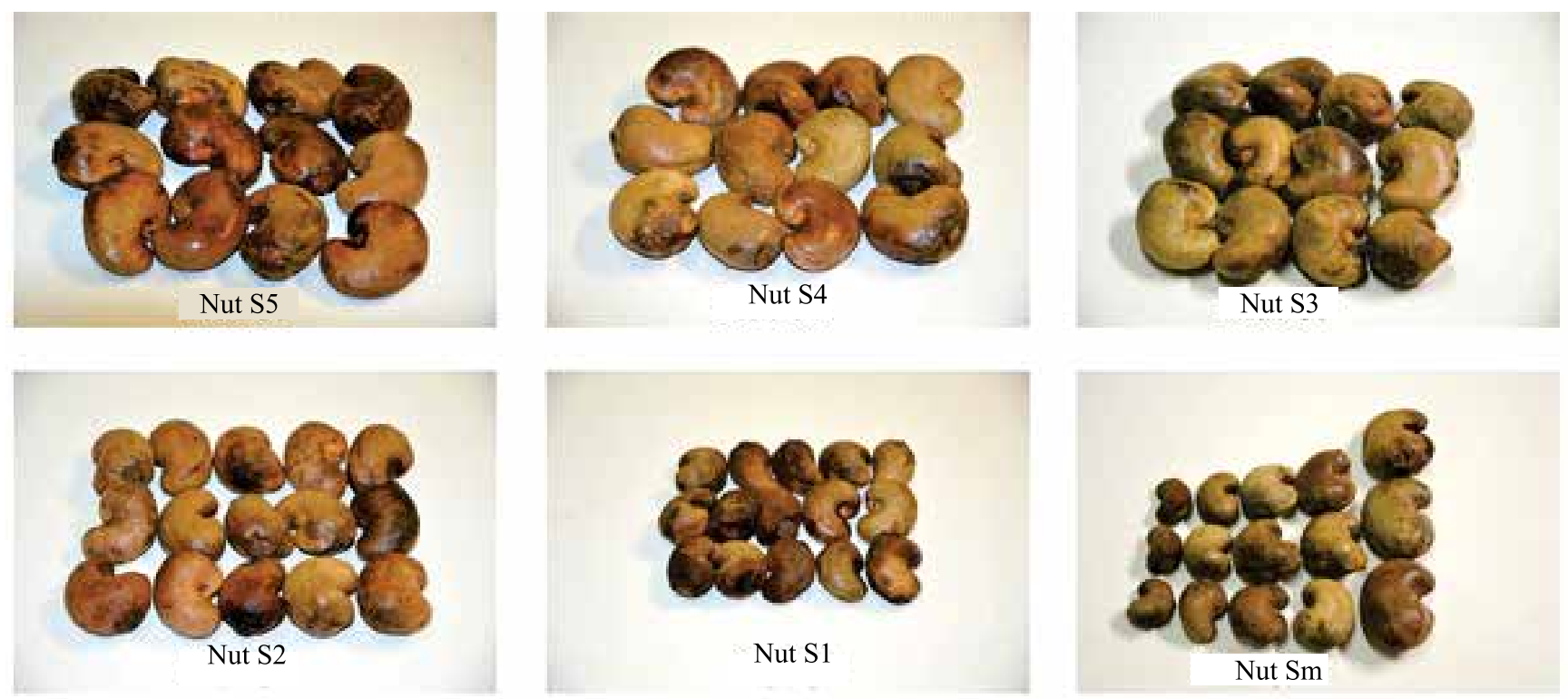

Figure 2. Cashew (Anacardium occidentale) nuts from each stratum under study (S5, S4, S3, S2, S1, and Sm). Photo by Cláudio de Norões Rocha.

\section{Conclusions}

1. Uniform stratified random sampling is an effective methodology for estimating cashew (Anacardium occidentale) nut size samples.

2. The evaluation of nut size (based on weight) should precede the definition of sample size to be collected for the analysis of morphological characteristics.

3. The sample size of cashew nut, for the purpose of morphometric evaluation, depends on the variance of the stratum (nut size), as well as on the error level permitted, or tolerated, in the estimates, and on the desired precision in the results.

4. The stratum formed by a mixture of nuts of various sizes should not be used as a parameter in this context.

5. The size of the sample to be taken should be established based on the error permitted as acceptable and on the degree of precision desired in the result by the researcher.

\section{Acknowledgments}

To Mr. Francisco de Assis Marinho, technician, and his assistant, Mr. David de Souza Costa, for their help in weighing and evaluating the nuts.

\section{References}

ALIYU, O.M. Phenotypic correlation and path coefficient analysis of nut yield and yield components in cashew (Anacardium occidentale L.). Silvae Genetica, v.55, p.19-24, 2006. DOI: https://doi.org/10.1515/sg-2006-0004.

ALIYU, O.M.; AWOPETU, J.A. Variability study on nut size and number trade-off identify a threshold level for optimum yield in cashew (Anacardium occidentale L.). International Journal of Fruit Science, v.11, p.342-363, 2011. DOI: https://doi.org/10.1080 /15538362.2011.630297.

ALMEIDA, J.I.L. de; ARAÚJO, F.E.; LOPES, J.G.V. Estudo preliminar das características físicas das castanhas de progêniesmatrizes de cajueiro-anão-precoce. In: EMPRESA DE PESQUISA AGROPECUÁRIA DO CEARÁ. Relatório anual de pesquisa 1980/1992. Fortaleza, 1992. v.1, p.81-85.

BARROS, L. de M.; CRISÓSTOMO, J.R.; PAIVA, J.R. de; OLIVEIRA, V.H. de. $\mathrm{O}$ agronegócio do caju. In: ALBUQUERQUE, A.C.S.; SILVA, A.G. da. (Ed.). Agricultura tropical: quatro décadas de inovações tecnológicas, institucionais e políticas. Brasília: Embrapa Informação Tecnológica, 2008. v.1, p.341-357.

BRASIL. Ministério da Agricultura, Pecuária e Abastecimento. $\operatorname{Portarian}^{\circ} 644$, de 11 de setembro de 1975. [Aprova as especificações anexas para padronização, classificação e comercialização da amêndoa e castanha de caju]. Diário Oficial [da] República Federativa do Brasil, 4 nov. 1975. Seção 1, p.3977. Available at: $<$ http://sistemasweb.agricultura.gov.br/sislegis/action/detalhaAto. do method $=$ visualizarAtoPortal Mapa $\&$ chave $=571135362>$. Accessed on: Oct. 152017. 
CAVALCANTI, J.J.V.; SANTOS, F.H.C. dos; SILVA, F.P. da; PINHEIRO, C.R. QTL detection of yield-related traits of cashew. Crop Breeding and Applied Biotechnology, v.12, p.60-66, 2012. DOI: https://doi.org/10.1590/S1984-70332012000100008.

CHACKO, E.K. Evaluating cashew hybrids in Northern Australia: report for the Rural Industries Research and Development Corporation. Barton: RIRDC, 1997. 43p. (RIRDC. Research paper series, n. 97/56). Available at: <https://trove. nla.gov.au/work/24182225? selectedversion=NBD13477607 $>$. Accessed on: Oct. 152017.

COCHRAN, W.G. Sampling techniques. $3^{\text {rd }}$ ed. New York: J. Wiley \& Sons, 1977. 428p.

GARRUTI, D. dos S.; CORDEIRO, E.R. Características biométricas e indicadores tecnológicos da castanha em quatro clones de cajueiro-anão-precoce. Fortaleza: EMBRAPACNPAT, 1993. 4p. (EMBRAPA-CNPAT. Pesquisa em andamento, 12). Available at: <https://www.infoteca.cnptia.embrapa.br/ handle/doc/419315>. Accessed on: Oct. 152017.

GARRUTI, D. dos S.; LIMA, J.R.; LIMA, A.C.; PAIVA, F.F. de A.; BARROS, M.E.S.; MORAES, I.V.M. de; ABREU, F.A.P. de; MACHADO, T.F.; BASTOS, M. do S.R.; SILVA NETO, R.M. da; SOUZA FILHO, M. de S.M. de; NASSU, R.T. Aproveitamento industrial. In: ARAÚJO, J.P.P. de (Ed.). Caju: o produtor pergunta, a Embrapa responde. 2.ed. rev. e atual. Brasília: Embrapa, 2015. p.187-238. (Coleção 500 perguntas, 500 respostas).

LIMA, A. C. Colheita e pós-colheita da castanha-de-caju. In: ARAÚJO, J.P.P. de. (Ed.). Agronegócio caju: práticas e inovações. Brasília: Embrapa, 2013. Cap.1, p.377-387. Available at: $<$ http:// www.ceinfo.cnpat.embrapa.br/arquivos/artigo_4155>. Accessed on: Oct. 152017.

LIMA, J.R.; SOUZA, A.C.R. de; PINTO, C.O. Protocolo para avaliação de castanhas-de-caju dos experimentos com progênies na Embrapa Agroindústria Tropical. Fortaleza: Embrapa Agroindústria Tropical, 2015. 7p. (Embrapa Agroindústria Tropical. Comunicado técnico, 215). Available at: <https://www.embrapa.br/en/agroindustria-tropical/buscade-publicacoes/-/publicacao/1030035/protocolo-para-avaliacaode-castanhas-de-caju-dos-experimentos-com-progenies-naembrapa-agroindustria-tropical>. Accessed on: Oct. 152017.

PAIVA, F.F. de A.; SILVA NETO, R.M. da. Processamento industrial da castanha-de-caju. In: ARAÚJO, J.P.P. de. (Ed.). Agronegócio caju: práticas e inovações. Brasília: Embrapa, 2013. Cap.3, p.395-465. Available at: <http://www.ceinfo.cnpat. embrapa.br/arquivos/artigo_4157>. Accessed on: Oct. 2017.

PAIVA, J.R. de; BARROS, L. de M.; CAVALCANTI, J.J.V.; LIMA, A.C.; CORRÊA, M.C. de M.; MELO, D.S.; PORTO, Z.B. Seleção de clones de cajueiro-anão precoce para plantio comercial no Município de Aracati, CE. Revista Ciência Agronômica, v.36, p.338-343, 2005. Available at: <http://www.ccarevista.ufc. br/seer/index.php/ccarevista/article/view/248/243>. Accessed on: Oct. 152017.

PFEFFERMANN, D.; RAO, C.R. (Ed.). Sample surveys: design, methods and applications. North Holland: Elsevier, 2009. 722p. (Handbook of Statistics, 29A).

RIBEIRO, J.L.; RIBEIRO, V.Q.; SILVA, P.H.S. da; RIBEIRO, H.A.M. Comportamento produtivo de oito clones de cajueiroanão-precoce em cultivo de terceiro ano sob regime de sequeiro. Teresina: Embrapa Meio-Norte, 2004. 4p. (Embrapa Meio-Norte. Comunicado técnico, 158). Available at: <https:// www.embrapa.br/en/busca-de-publicacoes/-/publicacao/67302/ comportamento-produtivo-de-oito-clones-de-cajueiro-anaoprecoce-em-cultivo-de-terceiro-ano-sob-regime-de-sequeiro $>$. Accessed on: Oct. 152017.

ROSSETTI, A.G. Precisão experimental e tamanho da área de experimentos de campo com fruteiras e outras plantas perenes arbóreas em função da unidade experimental e do número de repetições. Revista Brasileira de Fruticultura, v.23, p.704-708, 2001. DOI: https://doi.org/10.1590/S0100-29452001000300052.

RYAN, T.P. Sample size determination and power. New Jersey: J. Wiley, 2013. 404p.

SABINO, C.M.; VILLAÇA, R. Estudo comparativo de métodos de amostragem de comunidades de Costão. Revista Brasileira de Biologia, v.59, p.407-419, 1999. DOI: https://doi.org/10.1590/ S0034-71081999000300005.

SARDINHA, R.M.A.; BESSA, A.M.S.; TAMBÁ-BUNGÉ, P.; SERAFIM, M. Physical characterization of cashew (Anacardium occidentale L.) nuts produced by selected trees in GuineaBissau. In: INTERNATIONAL CASHEW AND COCONUT CONFERENCE, 1997, Dar es Salaam. Trees for life: the key to development: proceedings. Reading: BioHybrids International, 1998. p.121-127. Edited for C.P. Topper, P.D.S. Caligari, A.K. Kullaya; S.H. Shomari, L.J. Kasuga, P.A.L. Masawi; A.A. Mpunami. Available at: $<$ http://agris.fao.org/agris-search/search. do?recordID=GB1999001152>. Accessed on: Oct. 152017.

SCHEAFFER, R.L.; MENDENHALL III, W.; OTT, R.L.; GEROW, K.G. Elementary survey sampling. $7^{\text {th }}$ ed. Boston: Cengage Learning, 2011. 436p.

THOMPSON, S.K. Sampling. $3^{\text {rd }}$ ed. New Jersey: J. Wiley \& Sons, 2012. 472p.

VALE, E.H.; HAWERROTH, M.C.; CAVALCANTI, J.J.V.; VIDAL NETO, F. das C.; MELO, D.S. Desempenho de híbridos de cajueiro-anão-precoce no litoral do estado do Ceará. Revista Brasileira de Fruticultura, v.36, p.940-949, 2014. DOI: https://doi.org/10.1590/0100-2945-403/13. 